\title{
KIDNEY GRAFT REJECTION AFTER SILICONE BREAST IMPLANT SURGERY
}

\author{
Damir Peličić1,2, Batrić Vukčević2, Marina Ratković2,3, Danilo Radunović3, \\ Nemanja Radojević2,4
}

\begin{abstract}
In the patient presented in this study, bilateral breast implant surgery was performed by a submuscularly placed silicone gel implant. Unfortunately, a surgical team from another healthcare facility did not consult a nephrologist before the surgery, which was a necessary step in order to adjust the dosage of immunosuppressive therapy. During the early postoperative period, the patient developed febrility and acute mastitis, as well as acute renal transplant rejection. The patient was hospitalized at the Clinic of Nephrology, Clinical Center of Montenegro. After two weeks of treatment and care, her kidney transplant function recovered.
\end{abstract}

Acta Medica Medianae 2020;59(3):105-107.

Key words: transplantation, acute renal rejection, silicone implant

\author{
${ }^{1}$ Center for Science, Clinical Center of Montenegro, Podgorica, \\ Montenegro \\ ${ }^{2}$ Faculty of Medicine, University of Montenegro, Podgorica, \\ Montenegro \\ ${ }^{3}$ Department of Nephrology and Hemodialysis, Clinical Center \\ of Montenegro, Podgorica, Montenegro \\ ${ }^{4}$ Department of Forensic Medicine, Clinical Center of \\ Montenegro, Podgorica, Montenegro
}

Contact: Damir Peličić

Ljubljanska bb, 20000 Podgorica, Montenegro

E-mail: damir.pelicic@kccg.me

\section{Introduction}

Renal transplantation is a method of choice for treatment of end-stage renal disease. It requires permanent use of immunosuppressive drugs for prevention of acute rejection. Although antigen-dependent immune responses have traditionally been considered critical for induction of both acute and chronic allograft rejection, there is accumulating evidence supporting the observation that antigen-independent injury and subsequent inflammation may trigger allograft rejection. There is no data on the use of silicone breast implants in renal transplant recipients $(1,2)$.

\section{Discussion}

A 49-year-old woman with end-stage renal disease was treated with hemodialysis for three months, after which a cadaveric kidney transplantation was performed. Her posttransplant immunosuppressive protocol included cyclosporin, mycophenolate mofetil and prednisolone. Three years later, she was diagnosed with right-sided breast cancer, treated with right mastectomy and radiotherapy. Throughout this period, the kidney graft function remained satisfactory. Eighteen months after the right mastectomy, the patient was diagnosed with cancer in her left breast, treated with left mastectomy, after which she requested bilateral breast reconstruction for aesthetic reasons. A bilateral breast implant surgery was performed with the submuscularly placed silicone gel implant. Unfortunately, the surgical team that performed the breast implant surgery did not consult a nephrologist prior to the operation, which was a necessary step in order to adjust the dosage of immunosuppressant drugs. During the early postoperative period, she developed fever and acute mastitis (C-reactive protein level of $168 \mathrm{mg} / \mathrm{L}$ with pain and serohemorrhagic discharge from breasts), as well as acute kidney graft rejection (creatinine level of $178 \mu \mathrm{mol} / \mathrm{L}$, blood urea nitrogen level of 7.3 , creatinine clearance of $0.36 \mathrm{ml} / \mathrm{s}$ and proteinuria of $2.98 \mathrm{~g} / 24 \mathrm{~h}$ with a diuresis of $2000 \mathrm{ml}$, and echosonographic signs of acute graft rejection). She exhibited generalized edema with a body mass of 78 $\mathrm{kg}$. Also, drug monitoring showed a cyclosporine level of $71.8 \mathrm{ng} / \mathrm{mL}$. A sudden failure of graft function required pulse corticosteroid therapy with the adjustment of the immunosuppressive regimen, as well as a broad-spectrum antibiotic therapy. After two weeks of treatment, the graft function recovered. On discharge, the creatinine clearance was 0.57 $\mathrm{ml} / \mathrm{s}$. Also, there was a marked decrease in proteinuria $(0.08 \mathrm{~g} / 24 \mathrm{~h}$ with a diuresis of $2600 \mathrm{ml})$, and 
her body mass was reduced to $72 \mathrm{~kg}$. Cyclosporine level was $112.1 \mathrm{ng} / \mathrm{mL}$. The inflammation of the breasts also subsided, and her clinical course is uneventful to this day, with a good renal function. Immunosuppressed kidney recipients have a higher incidence of malignant tumors in comparison with the general population, with overall risks ranging from 3.3 to 3.6. $(3,4)$. However, the relative risk for breast cancer is 0.7 , meaning that immunosuppression may not increase the incidence of breast malignancy $(3,5)$. There are hypotheses considering the role of oncogenic viral infections flaring up during immuno-suppression, as well as the depressed immune reaction to tumor antigens (3). Of 2.139 kidney recipients described in a study by Kwak et al., 11 patients suffered from breast cancer, with a similar prognosis to the general breast cancer population. The authors emphasize the importance of immunosuppressant adjustment and hemodialysis access in posttransplant cancer treatment (4). On the other hand, exposure to silicone potentially results in autoimmune phenomena, due to the fact that silicone is not immunologically inert $(6,7)$.

\section{Conclusion}

In this case, it is plausible that silicone triggered an immune reaction to the kidney graft - a complication of breast augmentation that has not been described before. This report serves to illustrate the need for a nephrologist consultation and the adjustment of immunosuppressants in breast implantation surgery of kidney recipients.

\section{Conflict of interest}

The authors declare no conflict of interest.

\section{References}

1. Janowsky EC, Kupper LL, Hulka BS. Meta-analyses of the relation between silicone breast implants and the risk of connective-tissue diseases. N Engl J Med 2000; 342:781-790. [CrossRef][PubMed]

2. Lipworth L, Holmich LR, McLaughlin JK. Silicone breast implants and connective tissue disease: no association. Semin Immunopathol 2011;33:287-294. [CrossRef][PubMed]

3. Agraharkar ML, Cinclair RD, Kuo YF, Daller JA, Shahinian VB. Risk of malignancy with long-term immunosuppression in renal transplant recipients. Kidney Int 2004;66(1):383-389. [CrossRef][PubMed]

4. Kwak HY, Chae BJ, Bae JS, Jung SS, Song BJ. Breast cancer after kidney transplantation: a single institution review. World J Surg Oncol 2013;11:77.

[CrossRef][PubMed]

5. Stratta P, Morellini V, Musetti C, Turello E, Palmieri D, Lazzarich $\mathrm{E}$, et al. Malignancy after kidney transplantation: results of 400 patients from a single center. Clin Transplant 2008;22(4):424-447.

[CrossRef][PubMed]

6. Hajdu SD, Agmon-Levin N, Shoenfeld Y. Silicone and autoimmunity. Eur J Clin Invest 2011;41(2):203-211. [CrossRef][PubMed]

7. Cohen Tervaert JW, Kappel RM. Silicone implant incompatibility syndrome (SIIS): a frequent cause of ASIA (Shoenfeld's syndrome). Immunol Res 2013; 56(2-3):293-298. [CrossRef][PubMed] 


\title{
ODBACIVANJE BUBREŽNOG GRAFTA NAKON UGRADNJE SILIKONSKIH IMPLANTATA U DOJKE
}

\author{
Damir Peličić1,2, Batrić Vukčević2, Marina Ratković2,3, Danilo Radunović3, \\ Nemanja Radojević2,4
}

\begin{abstract}
Kontakt: Damir Peličić
Ljubljanska bb, 20000 Podgorica, Crna Gora

E-mail: damir.pelicic@kccg.me
\end{abstract}

${ }^{1}$ Centar za nauku, Klinički centar Crne Gore, Podgorica, Crna Gora

2Univerzitet Crne Gore, Medicinski fakultet, Podgorica, Crna Gora

${ }^{3}$ Klinika za nefrologiju, Klinički centar Crne Gore, Podgorica, Crna Gora

${ }^{4}$ Centar za sudsku medicinu, Klinički centar Crne Gore, Podgorica, Crna Gora

Kod bolesnice, koju smo prikazali u ovom radu, izvedena je bilateralna operacija implantata dojki submuskularnom primenom implantata silikonskog gela. Nažalost, hirurški tim iz druge zdravstvene ustanove pre operacije nije konsultovao nefrologa, što je bilo neophodno za prilagođavanje doziranja imunosupresivne terapije. Tokom ranog postoperativnog perioda, kod bolesnice se razvila febrilnost, razvio se akutni mastitis i došlo je do akutnog odbacivanja grafta. Bolesnica je hospitalizovana na Klinici za nefrologiju Kliničkog centara Crne Gore. Nakon dve sedmice lečenja i nege, funkcija njenog transplantovanog bubrega se oporavila.

Acta Medica Medianae 2020;59(3):105-107.

Ključne reči: transplantacija, akutno odbacivanje bubrega, silikonski implantant 